\title{
多孔罂体を用いた能動熱遮断の非定常特性*
}

\author{
円 山重 直*1, 相原利雄*1, Raymond VISKANTA*2
}

\section{Transient Behavior of an Active Thermal Insulation System}

\author{
Shigenao MARUYAMA, Toshio AIHARA, and Raymond VISKANTA
}

\begin{abstract}
Transient behavior of an active thermal insulation system consisting of a semi-transparent porous medium with gas injection was considered. Numerical analyses were carried out on the semi -infinite layer of a porous medium, and hydrogen was chosen as the injected gas. During the early stages of heating, thermal penetration depth, surface temperature and surface heat flux do not depend on the gas injection velocity. As the heating time increases, the thermal penetration depth of the active thermal insulation system reaches a constant value for each gas injection velocity, and the surface heat flux vanishes keeping the back face at a low temperature. However, the thermal penetration depth of a conventional insulation without gas injection never reaches a constant value. Transient solid temperature distributions in the layer for two different surface boundary conditions are almost identical except in the vicinity of the surface.
\end{abstract}

Key Words: Active Thermal Insulation. Thermal Radiation, Porous Media, Transient Analysis, Combined Heat Transfer, High Temperature, Thermal Protection

1. 緒

ロケットノズルやスペースシャトル再突入時の熱遮 断, 新素材開発の炉や核融合炉壁の熱防御は，今後の 重要な技術課題の一つつでる。ロケットノズルの壁面 冷却法については, Suttonらが広範な解説と分類を 行っている(1)。各種の熱遮断技術の中で，一般に使用 される、多孔質体やグラスウールなどの繊維の集合体 を用いた従来の断熱法㳉，壁面が高温にさらされると 熱放射による伝熱が増加し，断熱性能が著しく低下す る.

Matthews らは多孔質体に強力な熱放射線を照射 した場合の非定常断熱性能を計測している、スペース シャトルの断熱夕イルは再突入時の非定常加熱による 熱遮断によって構造物を低温に保っているが，ある一 定時間の熱遮断を行うためにはかなり厚い断熱層が必 要となる。膜冷却や，しみだし冷却，アブレーション冷 却なよ゙の物質移動冷却 ${ }^{(3)}$ (、，熱防御に有効な手段の… つであり，矢野ら(は仕金属纎維の焼結体と水のしみだ

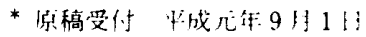

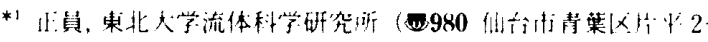
1-1).

*2 School of Mechanical Engineering. Purdue University (West Laffayette, IN 47907, U.S.A)
しによる防災ロボットの熱防御の基整研究を行ってい る。しかし，高温環境下に置かれた物体表面は，一般に 強力な熱放射線の照射を受ける場合が多く，吹出しガ スはこの熱放射線をほとんど吸収しないので，固体表 面は強力な熱放射線に直接さらされることになる。

一方，图1に示すような，光学的に半透過性で，微 細構造を有する織維の集合体や多孔質体の層に，低温 のガスを裹面から透過させる場合を考える，前面から 照射される熱放射線の大部分は，表面を透過して多孔 質層内部で吸収・散乱されるので，固体表面がさほど 高温にならずに済む。熱放射線で加熱された多孔質層 は，逆流する低温ガスによって効率上く冷却され，加 熱されたガスは系外に排出される。このような光学的 に半透過性り多孔質層々ガスの透過を組合せた能動熱 遮断の原理を芯用寸ることによって，高性能な断熱層 ができる叮能性がある。

上記の能動熱遮断の解析は, 熱放射・対流・伝導の複 合伝熱問題となるが，多孔質体の熱放射・伝導の解析 としては，Matthews ら ${ }^{(5)}$ の研究がある. 越後は, 高温 ガスを通気性固体に流すことによって，熱放射エネル ギーを閉じ込める原理を提唱し(6)，希薄ガス燃焼など の ${ }^{(7)}$ ‥連の研究在行っている。また，著者らは( ${ }^{(8)}$ 太陽炉 によって集光した光エネルギーを流動層によって効率 
よく高温ガスに変換できることを示し, Flamant ら (9) は, 固定層によって太陽エネルギーを高温ガスに変換 する研究を行った。

著者らは，能動熱遮断の解析のために数值解析を行 $い^{(10)}$, 常温の空気を流入させることによって約 1 $\mathrm{MW} / \mathrm{m}^{2}(2000 \mathrm{~K})$ の高温熱放射線を $5 \mathrm{~mm} の$ 多孔質 層で熱遮断できること，また，背面の温度を常温に保 ち，かつ熱漏えいをほほ完全に止めることができるこ とを明らかにした。さらに高温の熱放射に対しては， 熱解離ガスを作動ガスとして用いることの有用性を示 し、約 $5 \mathrm{MW} / \mathrm{m}^{2}(3000 \mathrm{~K})$ の熱放射線を $3 \mathrm{~mm}$ 程度の 多孔質層で熱遮断できることを明らかにしている(11). この能動熱遮断システムは，断熱の非定常特性にも大 きな特長を持っている.つまり，層厚さ $10 \mathrm{~mm}$ の本能 動熱遮断システムは, 同じ厚さのガスを透過しない従 来の多孔質断熱層に比べて, 約 $1 / 30$ の時間で定常状 態に達することができる(10).

本報では，上記の能動熱遮断の非定常特性を明らか にするために，半無限厚さの多孔質層を考え，その熱 放射・対流・伝導・非定常複合伝熱モデルの定式化と 数值解析を行う. 数值例から, 能動熱遮断における熱 浸透深さや局所熱流束, 層内温度の非定常特性を明的 かにする.

\section{2. 記 号}

$A_{c}, A_{a}, A_{g}$ : 熱伝導, 対流熱移動, 対流熱伝達の各パ ラメー夕 [式 $(19) \sim(21)]$

$A_{e}$ : 多孔質体の単位体積当たりの表面積 [式 ( 5 )]

$b, f:$ 前方および後方散乱成分

$C_{p y}, c_{s}:$ : スと多孔質体の比熱

$d_{p}:$ 多孔質体の等価直径

$E_{1}, E_{2}$ : 前面または背面における入射放射熱流束(図 1)

$h_{e}$ : 多孔質体と透過ガス間の熱伝達率

$k_{m}, k_{g}$ : 多孔質体とガスの熱伝導率

$m_{g}$ : ガスの質量速度

$n_{a}$ : 多孔質体の等価屈折率 [式(8)]

$N u_{p}$ : ヌッセルト数 $=h_{e} d_{p} / k_{y}$

$\operatorname{Pr}$ : プラントル数 $=\eta C_{p g} / k_{g}$

$q^{+}, q^{-}$: 前方抢よび後方放射熱流束

$q_{R}$ : 放射熱流束 $=q^{+}-q^{-}$

$q_{s}$ : 前表面からの対流による熱流束

$q_{t}:$ 多孔質体内の総括熱流束 [式 (2)]

$Q:$ 無次元熱流束 $=q /\left(E_{1}-E_{2}\right)$

$R e_{p}$ : 粒子レイノルズ数 $=m_{y} d_{p} / \eta$
$T_{1}, T_{2}$ : 境界における放射熱流束の特性温度（図 1 )

$T_{s}, T_{g}$ : 多孔質層内の固体温度とガス温度

$t:$ 時間

$t^{*}:$ 無次元時間 [ 式 (14)]

$x$ : 層表面からの距離 (図 1)

$x_{p 1}, x_{p 2}:$ 熱浸透媣さ [式(26)]

$\varepsilon_{s}$ : 層表面のふく射率(図 1)

$\theta_{s}, \theta_{g}:$ 多孔質固体とガスの無次元温度 [ 式(14)]

$\rho_{s}, \rho_{g}:$ 多孔質固体とガスの密度

$\sigma:$ スファン・ボルツマン定数

$\sigma_{e}:$ 多孔質体の減袁係数

$\tau:$ 光学厚さ $=x \sigma_{e}$

$\tau_{p 1}, \tau_{p 2}:$ 無次元熱浸透深さ [式(26)]

$\phi:$ 多孔質体の空げき率

$\omega_{0}:$ 多孔質体のアルベド

○：定常値の $99 \%$ に達したときの值

$\mathrm{BC} 1, \mathrm{BC} 2$ ：層表面の境界条件 [式(11)]

\section{3. 基礎式と物理モデル}

本報では，図 1 に示す光学的に半透過性で空げき率 が高い半無限厚さの多孔質体の一次元モデルを考え る. 多孔質体の前表面は，ある時間 $(t=0)$ から高温の 熱放射線にさらされる.多孔質層の背面から層前表面 に向かって低温がスが質量速度 $m_{9}$ で透過している。 高温放射熱流束 $E_{1}$ は，式(1)で表される特性温度 $T_{1}$ で評価する。

$$
E_{1}=\sigma T_{1}^{4}
$$

背面から流入するガス温度は， $T_{2}$ とする。

多孔質体の表面が $2000 \sim 3000 \mathrm{~K}$ の高温環境にさ らされる場合, 透過ガスの温度変化はかなり大きく $1000 \mathrm{~K}$ 以上にも達寸るため, ガスの物性值変化がか なり大きくなる，しかし著者らは, 透過ガスの温度変 化が大きいにもかかわらず，流体物性值の温度依存性

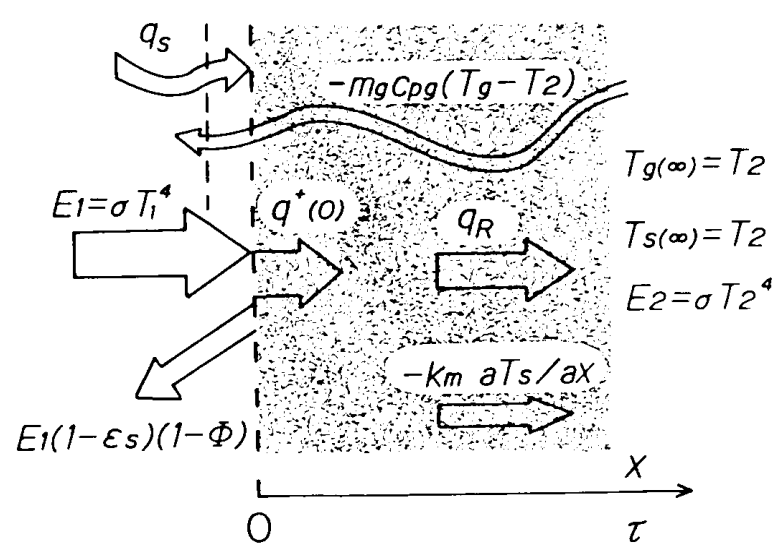

図 1 能動熱遮断層の物理モデル 
が断熱性能に及ほす影響は、特に非解離ガスの場合に は小さいことを示した(11).これらのことがらを考虑し て，本報では，多孔質体と透過ガスの物性値は温度に よらず一定とし， $T_{2}$ での値を用いることにする。また， 本研究で扱う多孔質体の厚さはたかだか数 $\mathrm{cm}$ であ り，空げき率もきわ奴いためにガス透過時の圧 力損失は数百 $\mathrm{Pa}$ であるので, ガスの静压 $(0.1 \mathrm{MPa})$ に比べて無視する。

したがって, 多孔質体内の総括熱流束 $q_{t}$ は, 次式で 示される。

$$
q_{t}=-k_{m} \frac{\partial T_{s}}{\partial x}+q_{R}-m_{g} C_{p g}\left(T_{g}-T_{2}\right)
$$

ここで，右辺第 1 項と第 2 項は，それぞれ熱流束の伝 導成分と熱放射成分を表し，正の值であり，図1に示 すように熱が前面から背面に向かって流れる。一方， 右辺第 3 項は透過ガスが多孔質体によって加熱される 対流熱移動(Heat Advection)成分を表している。この 成分は負の值であり，ガスのエンタルピーは背面から 全面に向かって移動する。

前面から入射した高温の熱放射線は，図1に示す上 うに一部は表面で反射されるが大部分は多孔質体内を 透過し散乱吸収される。熱伝導と熱放射によって加熱 き机た多孔質体は，背面からガスを透過させることに よって効率よく冷却され，熱伝導上熱放射による熱流 を能動的に遮断することができる。

流入ガスの単位体積当たりの熱鮞量は多孔質体に比 ベて 1/100〜 1/1000程度である(10)ので，ガスの非定 常温度変化に対寸る熱容重は近似的に無視することが できよう.さらに，前述のように，多孔質層の厚さは数 $\mathrm{cm}$ 程度であるので，流入ガスは熱放射に対して透明 であると仮定する。したがって，多孔質体とガスの工 ネルギー方程式は次式のようになる。

$$
\begin{aligned}
& (1-\phi) \rho_{s} c_{s}-\frac{\partial T_{s}}{\partial t}=\frac{\partial}{\partial x}\left(-q_{t}\right) \\
& =k_{m} \frac{\partial^{2} T_{s}}{\partial x^{2}}-\frac{\partial q_{k}}{\partial x}+m_{y} C_{p g} \frac{\partial T_{g}}{\partial x} \\
& -m_{y} c_{p g} \frac{\partial T_{y}}{\partial x}=A_{e} h_{e}\left(T_{s}-T_{g}\right)
\end{aligned}
$$

ここで，Aは多孔質体の単位体積当たりの有効表面 積であり，heは多孔質体単位面積当たりの有効熱伝 達率である。本報では，簡単のために，多孔質体泣直径 $d_{p} \sigma$ 単分散粒子の集合体であると仮定寸る。したがっ て，Aは次式で表寸ことができる。

$$
A_{e}=6(1-\phi) / d_{p}
$$

多孔質体内心熱伝達については，固定層や蓄熱式熱交 換器に関連して種々の研究があり，Wakaoら(12)は， それらけ実験結果をまとむた契験式を提出している。
しかし，本報で用いるような比較的微細な構造を有す る多孔質体に対し，低レイノルズ数領域における熱伝 達の研究は比較的少ない，本報では，Huberらは(13)の 下記の実験式を採用する。

$$
N u_{p}=0.054 \operatorname{Re}_{p}^{1.48}, 0.7<R e_{p}<16
$$

本解析で扱う多孔質体は，微細な粒子群で構成され ているとし，単‥粒子内す温度分布は無視する。しか し，その粒径はガスの平均自由行程に比心゙て十分大き いものと仮定する。

多孔質体の放射伝熱については多数の研究がある. 本研究で用いる多孔質体は，光学的に半透過性であり， アルベドが大きく散乱の指向性も高いために等方散乱 の仮定は導入しにくい. Menguc ら ${ }^{(14)} は$ ，放射伝熱の 諸種の近似解法を臀密解と比較し, 二流束 (ShusterSchwarzchild)近似が比較的良好な近似結果を与える ことを明らかにしている。一般に，物質の散乱吸収特 性は強い波長依存性を示すが，本報では解析を容易に するために，多孔質体は乍色体であると仮定する。以 上のことがらから，前方放射熱流束 $q^{*}$ と後方放射熱 流束 $q$ 次次式で近似される。

$$
\begin{aligned}
& \frac{1}{2} \frac{d q^{+}}{d \tau}=-\left(1-f \omega_{n}\right) q^{+}+\omega_{11} b q^{-} \\
& \quad+n_{a}^{2}\left(1-\omega_{0}\right) \sigma T_{s}^{4} \\
& -\frac{1}{2} \frac{d q}{d \tau}=-\left(1-f \omega_{0}\right) q^{-}+\omega_{0} b q^{+} \\
& \quad+n_{a}^{2}\left(1-\omega_{0}\right) \sigma T_{s}^{4}
\end{aligned}
$$

ここで，式(7)中の用折率 $n_{a}$ は，多孔質体のように 非均質媒体ひ場合には特別な扱いをする必要がある。 本報で㳉, 前報 ${ }^{(10)(11)}$ と同様に, 次式で表される Maxwell-Garnett が提示した ${ }^{(15)}$ 有効屈折率使用寸 ろ.

$$
n_{a}^{2}=n_{y}^{2} \cdot\left[\begin{array}{l}
n_{s}^{2}+2 n_{g}^{2}+2(1-\phi)\left(n_{s}^{2}-n_{y}^{2}\right) \\
n_{s}^{2}+2 n_{y}^{2}-2(1-\phi)\left(n_{s}^{2}+n_{g}^{2}\right)
\end{array}\right]
$$

ここで，ns と $n_{g}$ は固体とガスの屈折率である。式 (3)上式（７）は，次式によって関係づけられる。

$$
-\frac{\partial q_{k}}{\partial \tau}=2\left(1-\omega_{0}\right)\left(-q^{\cdot}-q^{-}+2 n_{a}^{2} \sigma T_{s}^{4}\right)
$$

ある時間 $t=0$ から多孔質層の前面 $(x=0)$ に $E_{1}=$ $\sigma T_{1}^{4}$ の熱放射線が照射されると，二の入射放射線の $\cdots$ 部が反射され，大部分が多孔質層内に透過吸收され る。したがーて， $x=0$ に㧈ける放射熱流束の境界条件 は，前報 ${ }^{(10)}$ と间样に次式で表される。

$$
x=0 \text { で } q^{\dagger}=\left\{\phi+\epsilon_{s}(1-\phi)\right\} E_{1}
$$

高温環境にさうされる多孔質体り表面は，一般に対流 に上る熱伀達を考えなけ扎法ならない。特に，ロケッ 卜ノズルや陆突入時の宇自往環機表面ではかなり大き な対流熱流束 $q_{\mathrm{s}}$ 老受ける(16)。しみだし泠却の既存の 
研究の多くは固体表面とガスの温度が等しいとしてい るが，本報の上うに固体表面が強い熱放射線にさらさ れる場合，固体・ガス間に大きな温度差を生じる(10)た めに，その熱伝達率の規定は難しい。そこで本報では， 以下に示寸二つの極限状態における境界条件考え る.

境界条件（1）(以下 BC 1 と略記寸る）：入射放射線 のみを考慮して対流伝熱は無視する。

境界条件 (2) (以下 BC 2 と略記する)：対流熱伝達 が非常に大きく，固体表面は前面の特 性温度 $T_{1}$ に等しい.

上記の境界条件は，次式で表される。

$x=0$ て

$$
\left.\begin{array}{lr}
-k_{m} \frac{\partial T_{s}}{\partial x}=(1-\phi) \epsilon_{s} \sigma\left[T_{1}^{4}-T_{s}^{4}(0)\right]: \mathrm{BC} 1 \\
T_{s}=T_{1} & : \mathrm{BC} 2
\end{array}\right\}
$$

前報(10)(11) と異なり，本報では厚さ無限大の一一次元モ

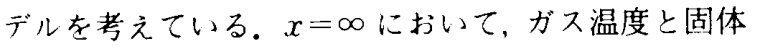
温度は等しく, 放射熱流束も平衡状態にあるから， $x$ $=\infty$ に打引境界条件は次式上なる。

$x=\infty$ で $T_{s}=T_{g}=T_{2}, q=E_{2}$

初期条件は次式で表される。

$t=0$ で $T_{s}=T_{g}=T_{2}, q^{*}=q^{+}=E_{2}$

\section{4. 無次元方程式と数值解法}

本報の熱放射・対流・伝導複合伝熱モデルでは，多孔 質内の固体温度とガス温度が大きく変化し，また，前 面に強力な $\left(E_{1}>1 \mathrm{MW} / \mathrm{m}^{2}\right)$ 熱放射線の照射を受け る。一方，本モデルは前報と異なり，多孔質層厚さが半 無限大であるため，層の厚さを基本長さとすることが できない，以上のことがらを考虑して，減衰率の逆数 $1 / \sigma_{e}$ を基本長さとし， $T_{1}, T_{2}, E_{1}, E_{2}$ を用いた，次式の 無次它童を導入する.

$$
\left.\begin{array}{l}
\theta_{s}=\left(T_{s}-T_{2}\right) /\left(T_{1}-T_{2}\right), \\
\theta_{g}=\left(T_{g}-T_{2}\right) /\left(T_{1}-T_{2}\right), \\
Q^{*}=q^{*} /\left(E_{1}-E_{2}\right), Q^{-}=q^{-} /\left(E_{1}-E_{2}\right), \\
t^{*}=\frac{t\left(E_{1}-E_{2}\right) \sigma_{e}}{(1-\phi) \rho_{s} C_{s}}, E_{b}=\frac{\sigma T_{s}^{4}}{E_{1}-E_{2}}
\end{array}\right\}
$$

上式を用いると，式(2)，(3)，(7)，(9)は次式に書 き換えられる。

$$
\begin{aligned}
& \frac{\partial \theta_{s}}{\partial t^{*}}=A_{c} \frac{\partial^{2} \theta_{s}}{\partial \tau^{2}}-\frac{\partial Q_{k}}{\partial \tau}+A_{a} \frac{\partial \theta_{g}}{\partial \tau} \\
& \frac{\partial \theta_{g}}{\partial \tau}=-A_{g}\left(\theta_{s}-\theta_{g}\right) \quad \ldots \ldots \ldots \ldots . . .
\end{aligned}
$$

$$
\left.\begin{array}{c}
\frac{1}{2} \frac{d Q^{+}}{d \tau}=-\left(1-f \omega_{0}\right) Q^{+}+\omega_{0} b Q+\left(1-\omega_{0}\right) E_{b} \\
-\frac{1}{2} \frac{d Q}{d \tau}=-\left(1-f \omega_{0}\right) Q^{-}+\omega_{0} b Q^{+}+\left(1-\omega_{0}\right) E_{b}
\end{array}\right\}
$$

式(15)，(16)中の $A_{c} ， A_{a}, A_{g}$ は，それぞれ放射伝熱に 対する熱伝導(Conduction)・対流熱移動(Heat Advection)・対流伝熱(Gas Convection)の各バラメータで, 次式で表される。

$$
\begin{aligned}
& A_{c}=\frac{k_{m} \sigma_{e}\left(T_{1}-T_{2}\right)}{E_{1}-E_{2}} \\
& A_{a}=\frac{m_{g} c_{p g}\left(T_{1}-T_{2}\right)}{E_{1}-E_{2}} \\
& A_{g}=\frac{6(1-\phi) N u_{p}}{\sigma_{e} d_{p} P r R e_{p}}
\end{aligned}
$$

式(14)の無次元化を行うことによって，境界条件式 (10)〜（12）と初期条件式 (13) は次式となる.

$$
\begin{aligned}
& \tau=0 て ゙ Q^{+}=\frac{\left\{\phi+\epsilon_{s}(1-\phi)\right\} E_{1}}{E_{1}-E_{2}} \\
& \tau=0 \text { で } \\
& \left.\begin{array}{ll}
-\frac{\partial \theta_{s}}{\partial \tau}=\frac{(1-\phi) \epsilon_{s} \sigma\left[T_{1}^{4}-T_{s}^{4}(0)\right]}{k_{m}\left(T_{1}-T_{2}\right)} & : \mathrm{BC} 1 \\
\sigma_{e} & : \mathrm{BC} 2
\end{array}\right\}
\end{aligned}
$$

$\tau=\infty$ で $\theta_{s}=\theta_{g}=Q^{-}=0$

$t=0$ で $\theta_{s}=\theta_{g}=Q^{-}=Q^{+}=0$

上記の問題は，式(15)に非線形項を含んだ連方微分 方程式となる。本問題は，不等間隔格子点を用いた差 分法によって, 式(15)〜（17）を順次反復し，各時間に おける収束解を求める手法を採用した。計算手法の詳 細については，既報(17)を参照されたい。ただし本解析 では、計算領域が半無限であるので，計算用格子点の 間隔は時間とともに増大し， $\tau=\infty に$ に打滰界条件 を満足するようにした。

\section{5. 結果と考察}

多孔質体の放射物性については，黑崎らの研究 ${ }^{(18)}$ はじめ数多くの研究がある。しかしながら，本研究で 用いる高耐熱性の多孔質体の熱物性值と放射物性值に ついて，相方を計測したデータは少ない。本報では，前 報と同様に Matthews らが計測した結果に基ー゙くジ ルコニア多孔質体の熱・放射物性值 ${ }^{(2)}$ を用いることに する。その物性值を表 1 に示寸。ここで，空げき率上等 価粒子直径は仮定された值である。

数值計算は, 前面の特性温度 $T_{1}$ を $3000 \mathrm{~K}$, 背面の 
温度 $T_{2}$ を $300 \mathrm{~K}$ として行った。このときの入射放射 熱流束は，4.6 MW $/ \mathrm{m}^{2}$ にのほる。作動ガスは, 前報 で(11)最も良好な熱遮断性能を示した水素ガスを選ん だ. 液体ロケットエンジンの泠却では，燃料の水素を 作動ガスとしてそのまま使うことができる点でも有利 であろう。前報(11)の解析によると，対流熱移動パラメ 一タ $A_{a}$ が熱遮断に重要な役割を果たしており，2> $A_{a}>1$ 程度で良好な断熱特性が得られることが明ら かとなっている，したがって，本報では $A_{a}$ が，2.0， $1.0,0.5,0.2$ となるように質量速度を選び, 数値計算 を行った，表 2 は，本計算条件における無次元パラメ

表 1 供試多孔質体の熱・放射物性

\section{Thermophysical Properties}

$\begin{array}{ll}c_{s}=1.75 \times 10^{3}[\mathrm{~J} / \mathrm{kg} \cdot \mathrm{K}] & \rho_{s}=5.6 \times 10^{3}\left[\mathrm{~kg} / \mathrm{m}^{3}\right] \\ k_{m}=7.0 \times 10^{-2}[\mathrm{~W} / \mathrm{m} \cdot \mathrm{K}] & d_{p}=10^{-4}[\mathrm{~m}]\end{array}$ $\phi=0.9$

$\begin{array}{ll}\quad \underline{\text { Radiation Properties }} & \\ \sigma_{e}=8.969 \times 10^{3}\left[\mathrm{~m}^{-1}\right] & \\ n_{s}=1.6 & n_{g}=0.2506 \\ \omega_{0}=0.99 & \epsilon_{o}=0.35\end{array}$

ータの値と, 有次元量を示している.

$5 \cdot 1$ 熱浸透深さの非定常特性高熱負荷下にお ける熱遮断で，必要断熱層厚さは重要な指標である。 そこで，本報では，熱が浸透する程度を表すハララメー 夕として，多孔質固体の無次元温度が $10 \%$ と $1 \%$ と なる層深さまたは光学厚さをもって，次式に示す熱浸 透深さを定義する。

$$
\left.\begin{array}{l}
x=x_{\rho 1}, \tau=\tau_{p 1} \text { で } \theta_{s}=0.1 \\
x=x_{p 2}, \tau=\tau_{p 2} \text { で } \theta_{s}=0.01
\end{array}\right\}
$$

図 2 ( a ), ( b ) は, 熱浸透深さの非定常変化を種々の $A_{a}$ について示したものである. 図 2 中には，ガスを透 過しない従来形の断熱層 $\left(A_{a}=0\right)$ と熱伝導のみの解

\begin{tabular}{|c|c|c|c|c|}
\hline \multicolumn{2}{|l|}{$A=$} & \multicolumn{3}{|l|}{0.369} \\
\hline$A_{a}=$ & 2.0 & 1.0 & 0.5 & 0.2 \\
\hline$A_{g}=$ & 0.085 & 0.061 & 0.044 & $0.02 x$ \\
\hline$m_{g}=$ & $0.23 x$ & 0.119 & 0.059 & {$\left[k: y / m^{2} s\right]$} \\
\hline $\begin{array}{l}t^{*}= \\
i=\end{array}$ & $\begin{array}{l}1 \\
6.4 x\end{array}$ & $-2[s]$ & $\begin{array}{l}\tau= \\
r=\end{array}$ & $\begin{array}{l}1 \\
0.111 \mathrm{mml}\end{array}$ \\
\hline $\begin{array}{l}l_{1}= \\
V_{1}=\end{array}$ & $\begin{array}{l}3000 \mid \\
4.6[\mathrm{M}\end{array}$ & & $\begin{array}{l}T_{2}= \\
E_{2}=\end{array}$ & $\begin{array}{l}300[\mathrm{~K}] \\
460\left[\mathrm{~W} / \mathrm{In}^{2}\right]\end{array}$ \\
\hline
\end{tabular}

\section{表 2 計算条件における無次元数と有次元量}

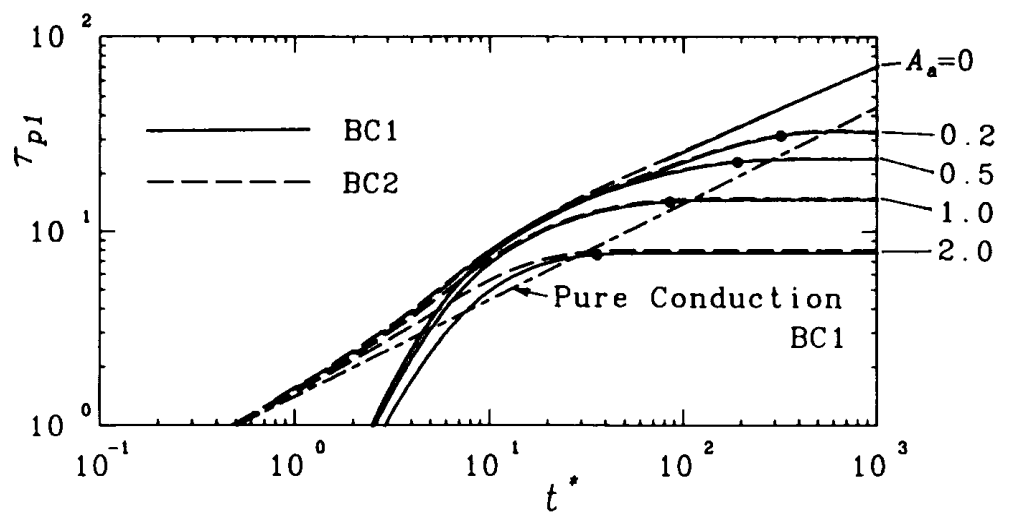

(a)

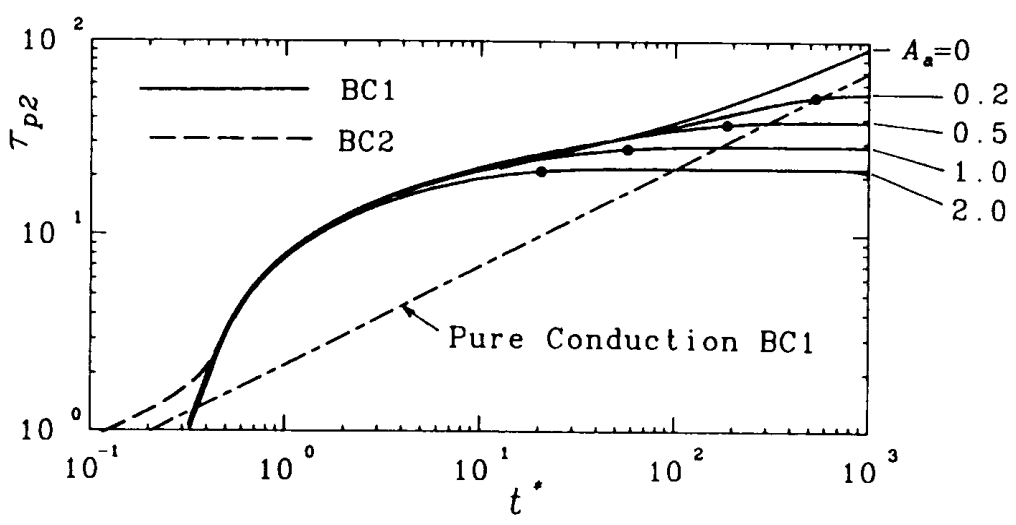

(b)

図 2 熱浸透梁さ $\tau_{p 1}, \tau_{p 2}$ J非定常変化 
析解 [ただし境界条件 (2)]も示してある.

加熱の初期段階ではガス透過の影響はほとんどな く，熱浸透深さは $A_{a}=0$ の場合と同様である。特に， BC 2 の場合における熱浸透深さは, 熱伝導のみの解 に漸近している．また，この領域では前面の境界条件 が熱浸透深さに大きく影響していることがわかる。

さらに時間が経過すると, 熱放射による伝熱のため に，熱伝導のみの場合に比べて熱浸透深さ $\tau_{p}$ が急激 に増大する.やがて，ガスを透過させた場合には，熱浸 透深さの発達は停此し, 定常の熱浸透深さが存在す る.熱伀導のみの場合や，伝導・放射モデル $\left(A_{a}=0\right)$ で はこのような定常状態が存在せず、時間の経過ととも に元が増大寸る.このように $\tau_{\rho}$ が有限值に収束する ことが，ガスを透過する本報の能動熱遮断の大きな特 長の一つである。

また図 2 を見ると境界条件の差異は, 加熱のごく初 期を除いてほとんど熱浸透深さに影響を与えないこと がわかる，これは，本解析で用いた多孔質体の減衰係 数 $\sigma_{e}$ が大きく, 熱浸透深さ $\tau_{p 1}, \tau_{p 2}$ における光学厚さ が大きいことが原因である.図 2 中には，BC 1 の場合 に $\tau_{p}$ が定常值の $99 \%$ に達したときをので示している が、 $\tau_{p 1}$ に比べて $\tau_{p 2}$ のほうが $A_{a}$ の変化に対する影響

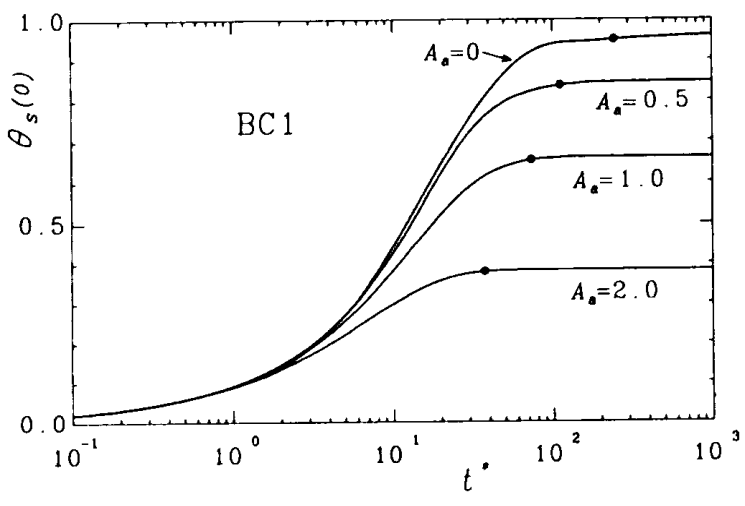

図 3 層表面に打ける固体温度の非定常変化 [ 境界条件（1）0場合]

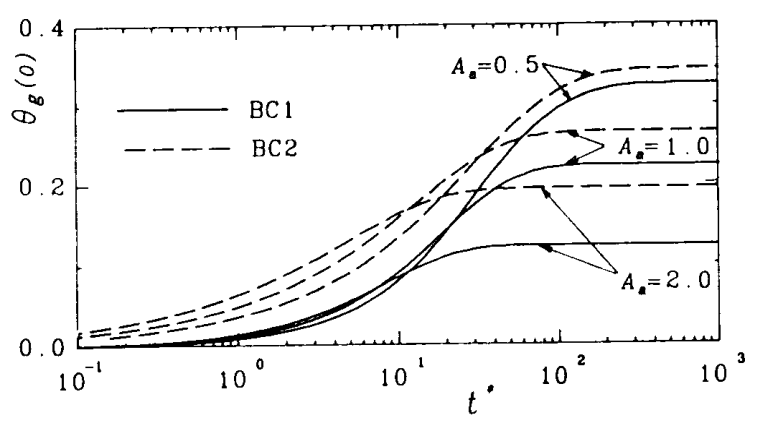

図 4 層表面に㧍ける噴出ガス温度の非定常変化
を強く受けることがわかる。

$5 \cdot 2$ 居表面の温度と熱流束の非定常变化

図 3

は，BC1における多孔質層表面温度の時間変化を， $A_{a}$ を種々変えて示したものである，加熱の初期段階 では，図 2 と同様にガス透過による影響は少なく，表 面温度の変化は $A_{a}$ によらず一様であるが, 時間の経 過とともに $\theta_{s}(0)$ は定常值となる。しかし，熱浸透深さ の場合と異なり， $A_{a}=0$ でも $\theta_{s}(0)$ は定常值が存在す る. 図 3 中, ○は定常温度の $99 \%$ に達した時間を示し ているが, 図 $2(\mathrm{~b})$ の場合ほど $A_{a}$ の影響を強く受け ていないことがわかる.

図 4 は前面におけるガス温度 $\theta_{g}(0)$ の時間変化を境 界条件と $A_{a}$ を種々変えて示したものである。図 3 の 場合と同椂に，ガス温度は時間とともに増大しやがて 定常になるが, その值は, 表面の境界条件の影響を強 く受け，BC 2 のほうが $\mathrm{BC} 1$ に比べてかなり大きく なる。特にその差異は， $A_{a}$ が大きいときに顥著であ る。これは，層表面近傍の固体温度分布 $\theta_{s}(\tau)$ が，境界 条件によって大きく異なるためである。

図 5 は，層表面における次式で定義の無次元総括熱 流束 $Q_{t}(0)$ の時間変化を, $\mathrm{BC} 1$ の場合について示し たものである.

$$
\tau=0 \text { で } \quad Q_{t}(0)=-A_{c} \frac{\partial \theta_{s}}{\partial \tau}+Q_{R}-A_{a} \theta_{g}
$$

無次元時間 $t^{*}$ が小さいときには, 固体・ガス温度とも に低いために，表面の熱流束は，放射熱流束のみとな り，ガス流束によらず一定値を取る。しかし，時間の経 過とともにQt(0)は急激に隇少してついに零となる。

図 2 を見ると明らかなように，熱浸透深さは $A_{a}=2$ で $x_{p 2}=2.4 \mathrm{~mm}$ と，きわて薄いことから，このごく 薄い層内で $T_{1}=3000 \mathrm{~K}$ の熱放射線を完全に遮断し, 襄面を常温で保ちつつ，かつ熱漏えいを完全に零にす ることができる。従来の断熱技術では，高温側からの 熱漏えいは避けられない。しかし，本報の能動熱遮断

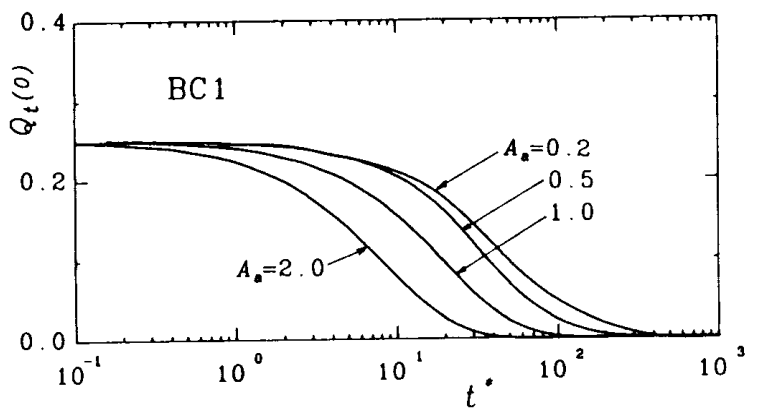

図 5 層表面に扔ける無次元熱流束の非定常変化 [ 境界条件 (1)0)場合 ] 
では，多孔質体が吸収した熱は層内を逆流するガスに よって効率よく冷却され，かつ熱を対流熱移動で逆流 させることによって，熱漏えいを完全に遮断すること ができる。図 5 から明らかなように，Aaが大きいほど $Q_{t}(0)$ が零となる時間が短いことがわかる.

$5 \cdot 3$ 非定常温度分布の变化 図 $6(\mathrm{a}) \sim(\mathrm{c})$ は， 層内固体温度 $T_{s}[\mathrm{~K}]$ の非定常変化を污元表示した ものである. 図6(a), (b)は, $A_{a}=1$ で BC 1 と BC 2 の境界条件の場合の固体温度 $T_{s}[\mathrm{~K}]$ を層表面から の距離 $x[\mathrm{~mm}]$ と加熱時間 $t[\mathrm{~s}]$ を軸に表したもので ある、比較のために，BC 1 でガスを透過しない場合の 固体温度の変化を図 6 (c) に示している。また図 6 中 には，熱浸透深さ $x_{p 1}, x_{p 2}$ の)変化を一点鎖線で表し，

で定常值の $99 \%$ に達した時間を示している.

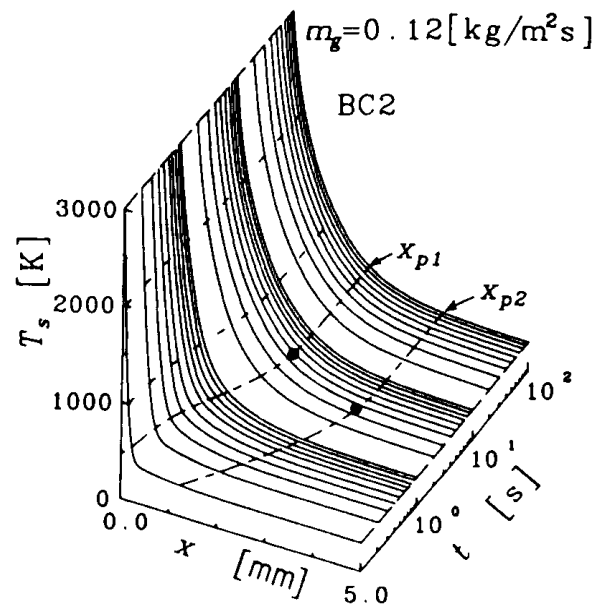

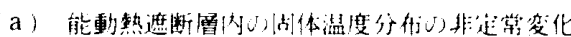

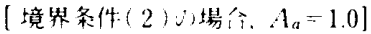

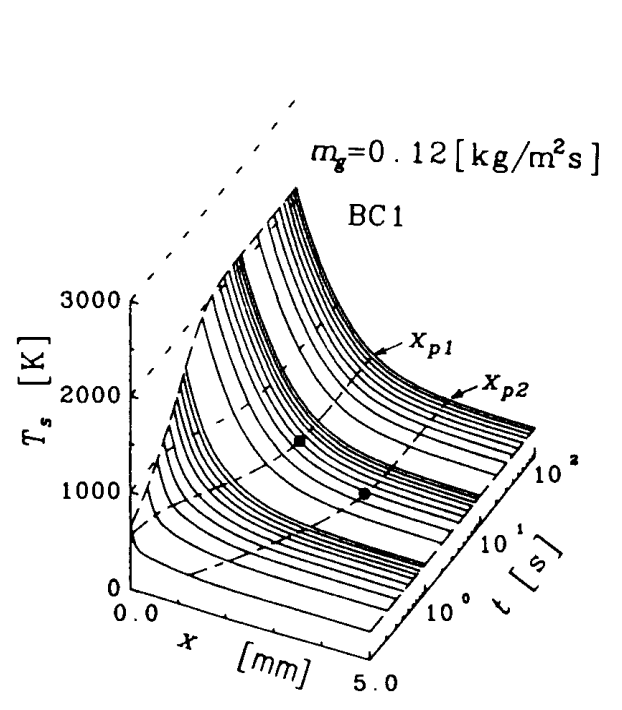

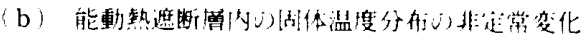

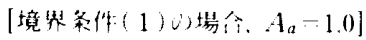

図 6（a），(b)を比較すると，両者は前面の境界条 件が全く異なるにもかかわらず，層表面ごく近傍を除 いてほほ等しい温度分布を示していることがわかる。 図6(a)，(b)ともに $x_{p 1}, x_{p 2}$ はそれぞれ1.6,3.2 $\mathrm{mm}$ であり，きわめて薄い層厚さで熱遮断が達成され ているのがわかる.また，その温度分布は，5 $\mathrm{s}$ 以下で 定常状態に達し，それ以後熱浸透深さは発達しない。

一方，図 6(c)に示すガスを透過しない従来形の多 孔質断熱層内の温度変化は, 図 6 ( a ), (b)のガスを 透過する能動熱遮断と大きく異なり，時間の経過とと もに熱浸透深さが急激に增大寸る，その值は， $t=100 \mathrm{~s}$ で $x_{p 1}=9.3, x_{p 2}=12.5 \mathrm{~mm}$ に発達している。

\section{6. 結}

光学的に半透過性で微細構造を有する織維の集合体 や多孔質体層に、低温のガスを裏面から透過させる能 動熱遮断について，半無限厚さの多孔質層を考え，そ の熱放射・対流・伝導・非定常複合伝熱モデルの定式 化と数值解析を行った，多孔質層の前面の特性温度を $3000 \mathrm{~K}$ とし，表面を $300 \mathrm{~K}$ として水素がスを透過ガ スとして用いた数值例から，能動熱遮断における熱浸 透深さや局所熱流束，層内温度分布の非定常特性を明 らかにした。得られた結果は下記のとおりである。

（1）熱浸透深さは，加熱の初期段階ではガス透過 の影響がほとんよ゙ないが，時間が経過すると，ガスを 透過させた場合には，熱浸透深さの発達は停止し，定 常の熱浸透深さが存在する，熱伝導のみの場合や，伝 導・放射モデルではこのような定常状態が存在せず，

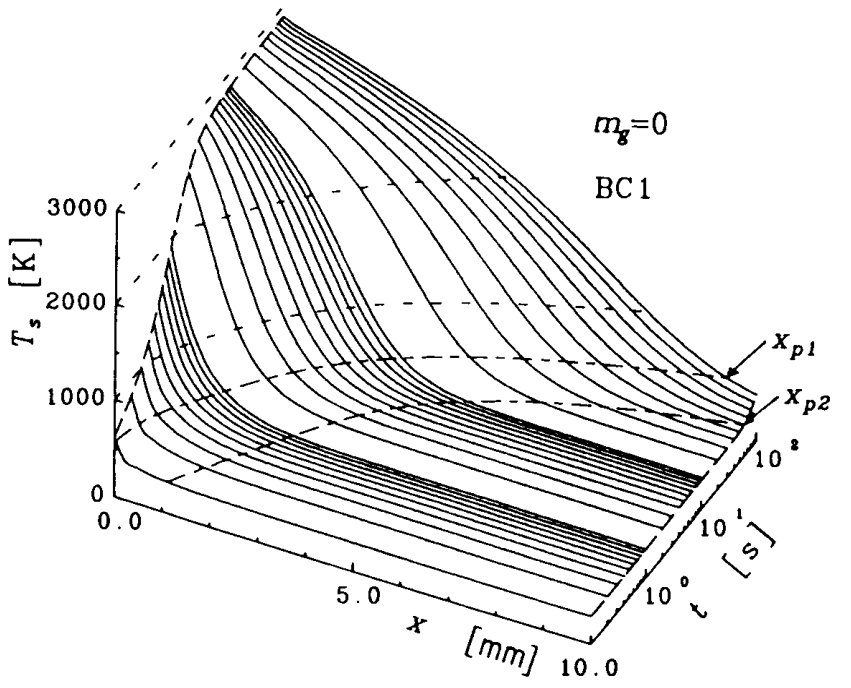

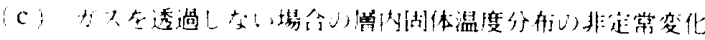

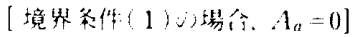

図 6 
時間の経過とともに熱浸透深さが発達する，層表面の 境界条件は, 加熱のごく初期段階を除いて, 熱浸透深 さに影響を与えない。

（2）無次元時間 $t^{*}$ が小さいときには, 層表面の 熱流束は，放射熱流束のみとなり，ガス流速によらず 一定值をとる。しかし，ガスを透過する本報の能動熱 遮断では，ごく短時間で表面の熱流束が急激に減少し， 多孔質体内全域で総括熱流束が零になる。つまり，本 能動熱遮断では，きわめて薄い断熱層内で高温の熱放 射線を遮断し，裹面を常温に保ち，かつ熱漏えいを零 にすることができる。

（3）本報の能動熱遮断では，層表面の境界条件が 異なっても，層表面ごく近傍を除いてほぼ等しい温度 分布を示し, ガス質量速度 $0.12 \mathrm{~kg} /\left(\mathrm{m}^{2} \cdot \mathrm{s}\right)$ で熱浸透深 さは $3.2 \mathrm{~mm}$ と, きわめて薄い層厚さで熱遮断が達成 される.また, その温度分布は，5 $\mathrm{s}$ 以下で定常状態に 達し，それ以後熱浸透深さは発達しない。

\section{文献}

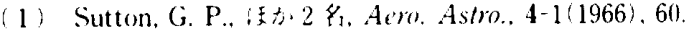

(2) Matthews, L. K.. Ift. 2 \%. Trans. ASME. J. Solar Energy Eng. 107 1(1985). 29

(3) Hartnett. J. P.. Handbon of Heat Transfer Ap. plications, 2nd. Ed., 1-1(1985). McGraw Hill.

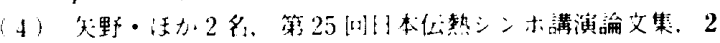
(1988), 187 .

(5) Matthews, L. K., 汪, 2 多, Int. J. Heat Mass Transf., $27-4(1984), 487$.

(6) 越後, 㙨論, 48-435. B(1982)，2135

（7）越後・传加 3 名，譏論，51-464，B (1985)，1297.

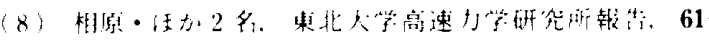
488(1989), 29.

(9) Flamant, T.. 2 多, Trans. ASME, J. Hot Transt. 110-2(1988), 463.

(10) Maruyama, S., 和 2 名, AIAA J. Thermo. Heat Tran. sf., 3(1989), 389 .

(11) Maruyama, S., 活か 2 名, Int. J. Heat Fluid Flow，(揭载 予定).

(12) Wakao. N.. 活3.2 名. Chom. Eng. Si., 34-3(1979), 325.

(13) Huber, M. L. and Jones, M. C.. Int. J. Heat Mass Transf., 31-4 (1988), 843.

(14) Menguc. M. P. and Viskanta. R., J. Quan. Spectresc. Radiat. Transf., 29-5(1983). 381.

(15) Reiss, H., Radiatice Transfer in Nontransparent Dispersed Media, (1988). 136. Springer-Verlag.

(16) Moss. J. N., 活 $\neq 2$ \%, AIAA 26th Aerospace Sicience Meeting. AIAA Paper, No. 88-0081(1988).

(17) Maruyama, S., 活 $2.2 \%$, AlAA 27 th Aerospace Sci ence Meeting, AIAA Paptr), No. 89-0605(1989).

(18) Kurosaki, Y., 年, 3 \%, Proc. ASME JSME The'mal Eng. Joint Conf., 4(1987), 319. 